\title{
Pemberdayaan Kelompok Tani pada Teknologi Pemanfaatan Energi Baru Terbarukan Berbasis Jarak Pagar untuk Percepatan Terbentuknya Desa Mandiri Energi di Kawasan Amor-Amor, Kabupaten Lombok Utara, NTB
}

\author{
Bambang Budi Santoso $^{\text {* }^{*}}$, I Wayan Suadnya ${ }^{2)}$, I Gst. Pt. Muliarta Aryana ${ }^{3)}$, \\ I Komang Damar Jaya ${ }^{1)}$ \\ ${ }^{1)}$ Pusat Kajian dan Pengembangan Tanaman Sumber Energi, Fakultas Pertanian, Universitas Mataram, \\ Mataram, INDONESIA \\ 2)Program Studi Agribisnis, Fakultas Pertanian, Universitas Mataram, Mataram, INDONESIA \\ 3) Pusat Kajian dan Pengembangan Pemulian Tanaman Pangan, Fakultas Pertanian, Universitas Mataram, \\ Mataram, INDONESIA
}

\author{
Article history \\ Received: 05 Maret 2019 \\ Revised: 14 Mei 2019 \\ Accepted: 14 Mei 2019 \\ *Corresponding Author: \\ Bambang Budi Santoso \\ Pusat Kajian dan \\ Pengembangan Tanaman \\ Sumber Energi, \\ Fakultas Pertanian, \\ Universitas Mataram, \\ Mataram, INDONESIA \\ bbsjatropha1963@gmail.com
}

\begin{abstract}
Jatropha curcas L. in the Amor-Amor, North Lombok, West Nusa Tenggara have been grown and developed long ago. It was just as fences of land, yards, and roads, and used as a source of traditional medicine but not as alternative energy sources and as a crop yield. Even if Jatropha seed oil can be used as an energy source family. No commercialize and intensively cultivation, such as the use of high yielding varieties, planting distance, fertilizing and other maintenance, and intercropping with food crops. Another problem faced by farmer groups members is difficult to get fertilizers, proper cultivation techniques, the difficulty of obtaining diesel fuel to operate the water borepumps for irrigation purposes. Through science and technology communication activities (Ipteks) was expected to formed the Energy Independent Village. This Ipteks such as counselling, training, and demonstrations conducted by the research team has been able to provide rationalization and true understanding to the farmer groups on aspects of Jatropha as an alternative source of fuel. Understanding includes benefits of crop as a source of fuel, good cultivation techniques, the potential economic and environmental impact, plant waste management and Jatropha seed oil processing and other benefits plant. Counselling and training undertaken has been able to generate interest and need for farmers to adopt the technology introduced. In addition, education and training was provided to farmers has also empowered them, by involving farmer participatory on any activities performed. Farmer's empowerment has successes. It was at the phase awareness, interest, and evaluation of the adoption process.
\end{abstract}

Keywords: alternative energy; independent; partisipative; seeds; training

Abtrak: Tanaman jarak pagar di kawasan Amor-Amor, Kabupaten Lombok Utara, Nusa Tenggara Barat sejak dahulu telah tumbuh dan berkembang dengan baik. Tanaman jarak pagar tersebut hanya sebagai pagar pembatas lahan, pekarangan, dan jalan desa, namun tidak dimanfaatkan dengan baik sebagai sumber energi alternatif atau hanya sekedar sebagai pengobatan tradisional dan bukan sebagai tanaman yang memberikan hasil atau pendapatan. Padahal minyak biji jarak pagar dapat digunakan sebagai sumber energi keluarga. Belum ada petani yang mengusahakan tanaman jarak secara intensif dengan menerapkan teknik budidaya yang baik maupun pertanaman 
secara tumpangsari. Permasalahan lain yang dihadapi anggota kelompok tani adalah kesulitan memperoleh pupuk, teknik budidaya yang benar, memperoleh bahan bakar minyak berupa solar untuk mengoperasikan mesin pompa air guna keperluan irigasi pertanaman maupun untuk keperluan rumah tangga. Melalui kegiatan Ipteks diharapkan terbentuk Desa Mandiri Energi. Kegiatan Ipteks ini berupa penyuluhan, pelatihan, dan demonstrasi yang dilakukan tim pelaksana IbM telah mampu memberikan pencerahan dan pemahaman yang benar kepada anggota kelompok tani terkait tanaman jarak pagar sebagai sumber alternatif bahan bakar. Pemahaman tersebut meliputi manfaat tanaman sebagai sumber bahan bakar, teknik budidaya tanaman yang baik, potensi ekonomis, dan pemanfaatan limbah pertanaman jarak pagar dan pengolahan minyak biji jarak pagar, serta manfaat lainnya. Penyuluhan dan pelatihan yang dilaksanakan sudah mampu membangkitkan minat dan kebutuhan petani untuk mengadopsi teknologi yang diintroduksi. Selain itu, penyuluhan dan pelatihan yang diberikan juga sudah memberdayakan petani, yaitu dengan partisipasi petani secara aktif pada setiap kegiatan yang dilakukan. Keberhasilan dalam pemberdayaan tampak pada kelompok tani saat ini telah melalui fase kesadaran, minat dan evaluasi pada proses adopsi.

Kata Kunci: biji; energi alternatif; mandiri; partisipasi; pelatihan

\section{PENDAHULUAN}

Krisis energi (bahan bakar minyak) yang melanda Indonesia mengharuskan pemerintah sekaligus masyarakat mencari sumber bahan bakar minyak alternatif. Bagi daerah-daerah dengan kawasan lahan kering dan marginal sumber alternatif tersebut adalah biofuel yang berasal dari minyak biji tanaman jarak pagar (Jatropha curcas L.).

Tanaman jarak pagar di kawasan Amor-Amor, Kabupaten Lombok Utara, Nusa Tenggara Barat (NTB) sejak dahulu telah tumbuh dan berkembang dengan baik. Tanaman jarak pagar tersebut hanya sebagai pagar pembatas lahan, pekarangan, dan jalan desa, namun tidak dimanfaatkan dengan baik sebagai sumber energi alternatif. Tanaman jarak pagar hanya dimanfaatkan sebagai bahan pengobatan tradisional dan bukan sebagai tanaman yang memberikan hasil atau pendapatan. Padahal minyak biji jarak pagar dapat digunakan sebagai sumber energi keluarga (Wiesenhutter, 2013). Belum ada petani yang mengusahakan tanaman jarak secara intensif dengan teknik budidaya baik, seperti penggunaan varietas unggul, pengaturan jarak tanam yang teratur, pemupukan dengan dosis maupun saat pemberian yang sesuai, dan pemeliharaan lainnya, maupun penerapan penanaman secara tumpangsari (Santoso et al.2017).

Pada sisi lain terdapat beberapa permasalahan lain yang dihadapi kelompok tani. Permasalahan tersebut adalah kesulitan memperoleh pupuk, teknik budidaya tanaman jarak pagar secara benar dan juga teknik bertanam tumpangsari dengan tanaman pangan, kesulitan memperoleh bahan bakar minyak berupa solar untuk mengoperasikan mesin pompa air guna keperluan irigasi pertanaman maupun untuk keperluan rumah tangga. Melalui kegiatan Ipteks berbasis jarak pagar yang telah dilakukan selama enam bulan diharapkan nantinya dapat mempercepat terbentuknya Desa Mandiri Energi. Artikel ini memaparkan hasil penyuluhan atau penerapan Ipteks yang bertujuan menyampaikan teknologi budidaya tanaman dan beberapa manfaat tanaman jarak pagar pada Kelompok Tani Lembah Telaga untuk percepatan terbentuknya Desa Mandiri Energi di Kawasan Amor-Amor, Kabupaten Lombok Utara, NTB. 


\section{METODE}

\section{Metode Penerapan Ipteks.}

Pemberdayaan masyarakat (kelompok tani Lembah Telaga) melalui IbM, yang digunakan adalah pendekatan pemberdayaan. Untuk dapat berdaya seseorang tidak hanya dengan memperoleh pengetahuan dan keterampilan baru, melainkan harus mampu menelaah secara mendalam dan menyesuaikan pengetahuan dan keterampilan yang diperoleh dengan kondisi pribadi dengan sistem sosial yang ada, sehingga sering pemberdayaan dianggap sebagai suatu pengembangan dalam diri individu itu sendiri (Staples, 1990).

Hall (1992) selanjutnya mengemukakan bahwa proses pemberdayaan itu dimulai dari menumbuh kembangkan kesadaran kritis bahwa individu sesungguhnya mampu untuk melakukan sesuatu untuk mempengaruhi dan mengontrol kehidupannya, kemudian mengambil inisiatif untuk belajar pengetahuan yang baru dan keterampilan baru. Selanjutnya mengekspos individu tersebut dengan pengalaman riil untuk menumbuhkan kepercayaan diri (Bembridge, 1991). Setelah itu, karena kepercayaan dirinya sudah tumbuh dan akan terus tumbuh maka diperlukan suatu media di mana individu mampu untuk ikut berpartisipasi baik dalam kegiatan kelompok maupun dalam masyarakat untuk secara aktif ikut berpartisipasi dalam mempengaruhi pengambilan Keputusan, pemanfaatan sumberdaya yang akan mempengaruhi kesejahteraan dan kehidupannya.

\section{Metode Pemberdayaan}

Pendekatan pemberdayaan kelompok tani Lembah Telaga dilakukan dengan menyelenggarakan penyuluhan berupa penyampaian materi terkait teknik budidaya tanaman jarak pagar baik secara monokultur, tumpangsari, maupun sebagai populasi pagar pembatas halaman rumah, dan berbagai aspek kegunaannya terutama sebagai sumber alternatif energi (bahan bakar minyak). Kegiatan juga dilakukan dengan menyelenggarakan demonstrasi terutama pada aspek pemanfaatan limbah pertanaman jarak pagar (kulit buah dan dedaunan) untuk dijadikan kompos sebagai sumber pupuk untuk usahatani mereka. Demonstrasi juga dilakukan pada teknik pemakaian kompor biji jarak pagar.

\section{HASIL DAN PEMBAHASAN}

\section{Pelatihan Penguatan Kelembagaan Kelompok Tani}

Kegiatan pelatihan penguatan kelompok diarahkan untuk peningkatan pemahaman dan pentingnya berkelompok dan dinamika kelompok (kindervatter, 1979). Pelatihan ini berdampak pada petani semakin memahami makna berkelompok dan menyatakan bahwa mereka saat ini telah merasakan betapa pentingnya bergabung dalam suatu kelompok. Hal ini dinyatakan oleh petani dengan menunjukkan bukti bahwa dengan berkelompok mereka akan mampu menyelesaikan persoalan dengan lebih mudah. Mereka juga menyatakan harapan dengan berkelompok mereka mampu untuk mendapatkan perhatian dari pemerintah dan diberikan bantuan terkait dengan pembentukan desa mandiri energi dalam rangka mewujudkan kemandirian energi serta diperhatikan oleh Fakultas Pertanian Unram.

Setelah pelatihan, petani lebih memahami hak dan kewajibannya sebagai anggota kelompok. Petani juga memahami tugas-tugas yang harus dilakukan oleh pengurus. Petani memahami bahwa dalam berkelompok, sering akan terjadi perbedaan pendapat dan kepentingan, namun mereka menyadari 
bahwa segala sesuatunya harus diselesaikan demi untuk kemajuan kelompok (memahami konflik dan penyelesaiannya).

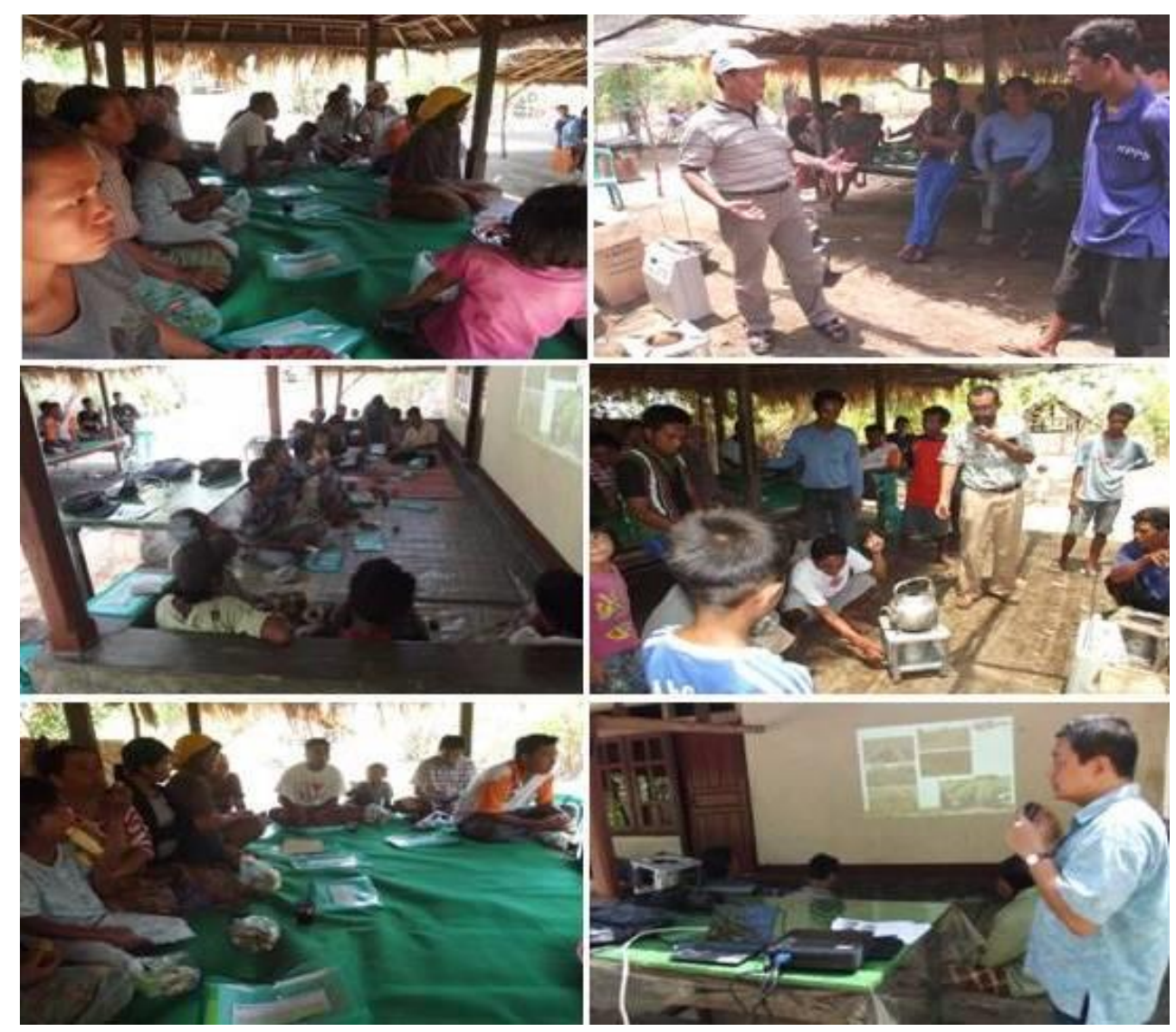

Gambar 1. Para anggota Kelompok Tani Lembah Telaga saat menerima materi penyuluhan dengan serius dan penuh perhatian klom kiri), tutor memberikan ceramah dan diskusi materi-materi penyuluhan (kolom kanan).

\section{Pelatihan Pembuatan Kompos Limbah Pertanaman Jarak Pagar}

Pelatihan pembuatan kompos dengan beberapa kegiatan diantaranya adalah pengenalan kompos, manfaat kompos, dan cara (demonstrasi dan praktek) pembuatannya. Hasil yang dicapai setelah mengikuti pelatihan antara lain petani mengetahui bahwa limbah pertanaman jarak pagar berupa kulit buah dan dedaunan serta ranting-ranting pohon dapat dimanfaatkan untuk membuat kompos yang dapat digunakan untuk menyuburkan tanah, sebagai pengganti pupuk urea/buatan pabrik. Petani mengetahui cara pembuatan dan mampu membuat kompos dari limbah pertanaman jarak pagar yang dikumpulkan dari areal pertanaman. Kompos yang dihasilkan dapat dijual dan menjadi salah satu sumber pendapatan kelompok. Selain itu, jika belum sempat dijual, kompos hasil buatan sendiri ini akan dapat digunakan untuk kepentingan pemupukan tanaman pangan maupun tanaman jarak pagarnya sendiri sehingga pembeliann pupuk kimia dapat ditekan.

\section{Pelatihan Teknik Budidaya Tanaman Jarak Pagar Sebagai Pembatas Pekarangan, Jalan Desa, dan Budidaya Secara Tumpangsari dengan Tanaman Pangan}

Kegiatan berupa pemaparan yang disertai diskusi pada aspek teknik budidaya tanaman jarak pagar. Kegiatan diikuti dengan demonstrasi beberapa aspek pemeliharaan dengan memanfaatkan areal 
pertanaman yang telah ada di sekitar lokasi kegiatan penyuluhan. Hasil yang dicapai adalah sebagian besar dari anggota dan pengurus kelompok dan juga istri serta anak-anak mereka sudah terlibat secara aktif khususnya pembibitan tanaman jarak pagar dan pemeliharaan tanaman. Dengan ikut aktifnya anggota kelompok dalam demplot pembibitan ini, mereka jadi lebih mengerti dan faham cara pembibitan tanaman jarak pagar. Dengan keterlibatan mereka dalam kegiatan ini mereka dapat secara langsung melihat pertumbuhan dan perkembangan bibit tanaman yang dipupuk dengan pupuk organik atau kompos.

Kegiatan penanaman dilakukan hanya secara simbolis saat pelaksanaan penyuluhan dan pembelajaran. Penanaman bibit tanaman pada pagar dilakukan hanya sepanjang 25 meter, yaitu pada pagar pembatas pekarangan Ketua Kelompok Tani Lembah Telaga. Kenyataan ini disebabkan keterbatasan waktu petani mempersiapkan tempat penanaman pada pagar pembatas pekarangan mereka.

Penanaman pada areal pertanaman baik secara monokultur maupun secara tumpangsari tidak dapat dilaksanakan sehubungan dengan belum tersedianya areal lahan untuk penanaman. Namun demikian dengan adanya areal pertanaman jarak pagar seluas 2 hektar milik Ketua Tim Pelaksanaan Ipteks ini, maka lokasi tersebut digunakan sebagai tempat pelatihan (kunjungan).

Melalui kegiatan kunjungan ke areal pertanaman jarak pagar tersebut, petani menjadi tahu dan mengerti cara budidaya tanaman jarak pagar. Respon petani sangat positif, terbukti dengan pernyataan petani yang menyatakan akan menerapkan cara ini pada pertanaman pagar pembatas dan kemudian encari areal lahan bersama untuk penanaman sistim perkebunan atau ditumpangsarikan dengan tanaman pangan. Namun demikian, dapat dikatakan bahwa akibat kegiatan Ipteks ini telah mampu menumbuhkan keinginan petani untuk mencoba di lahan mereka masing-masing.

Proses penerapan Ipteks yang dilaksanakan sudah sesuai dengan rencana dalam arti semua sebagian besar rencana kegiatan yang direncanakan dapat terlaksana dengan baik. Kegiatan telah dilaksanakan dengan menggunakan prinsip-prinsip pemberdayaan (Lord \& Hutchison, 1993; Putman, 1991). Petani dan kelompok tani telah diikutsertakan dalam proses ini. Mulai dari sosialisasi program sampai dengan demonstrasi dan pembelajaran teknik bercocok tanam tanaman jarak pagar dan pembuatan kompos berbahan baku limbah pertanaman jarak pagar. Kegiatan ini dilaksanakan pada periode yang relatif singkat yaitu dari tanggal Agustus sampai dengan awal Desember 2012. Walaupun demikian, hasil yang dicapai sudah memuaskan karena transfer pengetahuan, perubahan sikap, alih teknologi yang diharapkan sudah berjalan walaupun terlihat nyata bahwa anggota kelompok menerapkan teknologi yang dianjurkan. Berikut adalah pembahasan dan hasil evaluasi yang dilakukan terhadap kegiatan-kegiatan yang telah dilakukan.

Berdasarkan hasil evaluasi dari kegiatan pelatihan (penyuluhan) tampak peningkatan pengetahuan betapa pentingnya tanaman jarak pagar sebagai sumber bahan bakar rumah tangga, sikap dan keterampilan petani dalam bercocok tanam tanaman jarak pagar baik secara monokultur maupun tumpangsari serta pembuatan kompos berbahan baku limbah pertanaman jarak pagar. Setelah mereka mendapatkan pelatihan (penyuluhan) dan kunjungan lapangan ke areal pertanaman jarak pagar, petani saat ini sudah memahami dan mengetahui manfaat jarak pagar sebagai sumber alternatif bahan bakar mereka. Lebih jauh juga mereka menyatakan sikapnya yang positif, yaitu mereka ingin mempunyai alat pengepres biji jarak pagar agar mereka dapat memanfaatkan minyak biji jarak pagar sebagai bahan bakar minyak tidak hanya biji jarak pagar. Hal ini sejalan dengan teori adopsi yang dikemukakan oleh Roger (1983) bahwa setelah petani tahu dan memahami inovasi, mereka mempertimbangkan untuk mencoba inovasi tersebut. 
Dari hasil evaluasi dan pengamatan terhadap proses pelatihan pembuatan kompos bahwa telah terjadi peningkatan pengetahuan, sikap dan keterampilan petani dalam hal pembuatan kompos. Hal ini terungkap dari hasil tanya jawab terdapat beberapa anggota kelompok tani pernah mendengar dan tidak tahu tentang kompos limbah pertanaman jarak pagar, namun beberapa di antaranya menyatakan sebatas pernah mendengar. Setelah dilakukan pelatihan melalui beberapa tahapan proses mulai dari penjelasan, demontrasi pembuatan, dan juga melihat kompos hasil demonstrasi (praktek yang dilakukan beberapa orang anggota kelompok tani) terlihat jelas telah terjadi peningkatan pengetahuan, sikap dan keterampilan petani. Saat tanya jawab di sat penyuluhan berlangsung, mereka menyatakan sudah mengetahui, faham dan mengerti tentang kompos baik manfaatnya maupun proses pembuatannya. Sikap mereka juga terlihat sangat positif dengan menyatakan bahwa mereka siap untuk mencoba melalui kegiatan kelompok.

Budidaya tanaman jarak pagar baik sebagai populasi pagar pembatas pekarangan dan jalan desa maunpun sebagai pertanaman intensif dalam tumpangsarinya dengan tanaman pangan dan hortikultura merupakan salah satu tujuan yang ingin dicapai dalam penerapan Ipteks. Dari hasil evaluasi dan pengamatan diketahui bahwa telah terjadi perubahan pengetahuan, sikap dan keinginan petani dalam menerapkan budidaya tanaman jarak pagar sebagai sumber bahan bakar mereka.

Hasil pengamatan tim, diketahui bahwa tingkat partisipasi petani dalam pelatihan (penyuluhan) maupun demonstrasi pembuatan kompos dan praktek pembibitan tanaman dan penanaman tanaman jarak pagar sebagai populasi pagar pembatas tampak bahwa mereka penuh antusias bertanya. Beberapa orang anggota kelompok tani menyatakan kekagumannya terhadap penampilan tanaman jarak pagar yang ada di areal penelitian yang dikunjungi. Merekapun menyatakan akan melakukan penanaman tanaman jarak pagar sebagai pagar pembatas pekarangan dan kebun mereka. Dengan demikian dapat dikatakan bahwa proses transfer teknologi yang direncanakan sudah dapat dilakukan dan akan diterapkan kemudian oleh petani. Namun demikian, hal ini masih harus dibuktikan dan dipantau secara terus menerus apakah apa yang telah dikemukakan oleh petani tersebut akan menjadi kenyataan di lapangan. Oleh karena itu, sesungguhnya waktu yang disediakan untuk melakukan penerapan Ipteks ini tidak cukup untuk melaksanakan seluruh rangkaian kegiatan sampai terbentuknya Desa Mandiri Energi berbasis tanaman jarak pagar. Dalam proses menjadikan masyarakat perdesaan dapat mandiri energi dibutuhkan waktu yang cukup panjang. Program ini memerlukan waktu yang cukup panjang. Oleh karena itu, jika program ini diharapkan memberikan hasil maksimal kepada petani atau masyarakat perdesaan, maka program ini perlu dilanjutkan pada tahun berikutnya.

Terdapat beberapa faktor pendorong dan faktor penghambat pelaksanaan penerapan Ipteks ini. Faktor pendorongnya antara lain adalah tingkat partisipasi yang cukup tinggi dari anggota kelompok tani dan dukungan dari berbagai pihak termasuk PPL dan aparat desa. Keberadaan areal pertanaman jarak pagar yang merupakan areal penelitian Ketua Tim Ipteks ini juga memberikan dukungan untuk pelaksanaan kegiatan ini. Sikap kooperatif anggota dan pengurus kelompok tani dalam mengkoordinasikan dan melaksanakan kegiatan penerapan Ipteks merupakan hal terpenting. Sedangkan faktor penghambatnya adalah, terlambatnya turun dana dan ditandatanganinya kontrak sehingga waktu yang tersedia sangat singkat. Dengan keterlambatan turunnya dana maka terjadi penundaan kegiatan dan sebagaimana diketahui pembibitan tanaman dan juga musim tanam tidak dapat diundur, sehingga pekerjaanpun harus dilakukan dengan cepat agar tidak ketinggalan oleh musim tanam. 


\section{KESIMPULAN DAN SARAN}

Proses pelaksanaan kegiatan sudah dilaksanakan sesuai dengan rencana dan sesuai dengan pendekatan yang telah dirumuskan, walaupun ada beberapa perubahan dan modifikasi, hal tersebut tidak mengurangi efektifitas pelaksanaan kegiatan yang dimaksud. Proses yang dilaksanakan sudah mampu membangkitkan minat dan kebutuhan petani untuk mengadopsi teknologi yang diintroduksi. Penyuluhan dan pelatihan juga sudah memberdayakan petani, dan bahwa saat ini petani telah melalui fase kesadaran, minat dan evaluasi pada proses adopsi. Petani sudah berada pada tahap mencoba dan jika pendampingan diteruskan maka petani akan mencapai fase adopsi. Kegiatan penerapan Ipteks telah berhasil mentransfer pengetahuan dan teknologi kepada sasaran yaitu angota kelompok tani Lembah Telaga. Namun dibutuhkan waktu yang panjang untuk transformasi teknologi hingga terbentuknya Desa Mandiri Energi.

\section{Ucapan Terima Kasih}

Disampaikan kepada Direktorat Jenderal Pendidikan Tinggi, Kementerian Pendidikan dan Kebudayaan, yang telah mendanai kegiatan Ipteks bagi masyarakat (IbM) sesuai dengan Surat Perjanjian Pelaksanaan Penugasan Program Pengabdian Kepada Masyarakat 223/SP2H/KPM/DIT.LITABMAS/III/2012, Tanggal 6 Juli 2012,

\section{DAFTAR PUSTAKA}

Bembridge, T. 1991, Practical Guidelines For Agricultural Extension Workers, A Field Manual, Development Bank of Southern Africa, Halfway House.

Hall, C.M. 1992, Women and Empowerment: Strategies for Increasing Autonomy, Hemisphere Publishing Corporation, Washington.

Kindervatter, S. 1979. Non-formal Education as an Empowering Process With Case Studies from Indonesia and Thailand, Center for International Education, University of Massachusetts, Massachusetts.

Lord, J. \& Hutchison, P. 1993, The process of Empowerment: Implications for Theory and Practice', Canadian Journal of Community Mental Health, vol. 12, no. 1, pp. 5-22.

Putman, A. O. 1991. Empowerment: In Search of a Viable Paradigm, Performance Improvement Quarterly, vol. 4, i. 4, pp. 4-11.

Rogers, E. M. 1983, Diffusion of Innovations, Free Press, New York

Santoso, BB., Hariyadi, BS Purwoko. 2007. Tinjauan agro-morfologi perkecambahan biji jarak pagar (Jatropha curcas L.). J. Penelitian Universitas Mataram. Edisi Sain dan Teknologi. Vol.2 No.2. Agustus 2007.

Staples, L. H. 1990, Powerful Ideas About Empowerment, Administration in Social Work, vol. 14, no. 2, pp. 29-42.

Wiesenhutter, J. 2003. Use of Physic Nut (Jatropha curcas L.) to Combat Desertification and Reduce Poverty. Deutsche Gesellschaft fur Technsche Zusammenarbeit (GTZ). Convention Project to Combat Desertification (CCD Project). www.gtz.de/desert [September 2005]. 